\title{
Analyzing Growth Reactions of Herbaceous Plants for Irrigation Management
}

\author{
Myeong II Jeong, Na Ra Jeong*, Seung Won Han, and Jae Soon Kim \\ Researcher, National Institute of Horticultural and Herbal Science, Wanju 55365, Korea
}

\section{ABSTRACT}

Background and objective: The purpose of this study was to provide guidelines for irrigation management by analyzing the effects of soil moisture on the growth characteristics of herbaceous plants in green infrastructure.

Methods: In a rain shelter greenhouse, the growth performance of nine species of experimental plants was assessed under different soil moisture contents (20\%, 15\%, 10\%, 5\%, and 1\%) for about 5 months to analyze plant growth characteristics due to soil humidity. Methods to determine plant growth conditions include surveying growth conditions of the crowns, stems, leaves, flowers and fruits on the aerial part and surveying growth conditions of the roots in the underground part. Results: The results showed that Mukdenia rossii and Astilbe rubra grew well at 15\% moisture content with irrigation intervals of 10 and 13 days, respectively. Soil moisture content of $10 \%$ with irrigation intervals of 13 and 17 days was appropriate for Sedum kamtschaticum and Pachysandra terminalis. Similarly, Aquilegia japonica and Liriope platyphylla grew well at 15\% moisture content with irrigation intervals of 10 and 17 days. However, Ligularia stenocephala grew well-developed stems and roots at $1 \%$ soil moisture content and an irrigation interval of 25 days, while the optimum conditions for Lythrum anceps were 5\% moisture content and an irrigation interval of 8 days.

Conclusion: Although a limited number of experimental plants were used in this study, this study could propose an appropriate irrigation cycle for planting on artificial soil substrates. Based on these results, it is possible to plan suitable planting designs considered irrigation cycles.

Keywords: soil moisture content, irrigation interval, growth environmental management

\section{Introduction}

With emerging issues such as environmental pollution, urban heat island and urban flooding due to urbanization and climate change, the urban environment and ecosystem are deteriorating. These issues are caused by damaged forests, which are natural green spaces in the city. Natural greens, which had supplied oxygen, purified air, stored rainwater, prevented soil loss and provided habitats for wild animals, are now failing to faithfully fulfill their functions due to decreased areas with urban development. There is more and more attention in green infrastructure with the rising need to systematically manage green spaces to solve urban environmental problems.

Greening using artificial ground such as buildings, civil engineering structures and pavements that take up most of the city is an alternative to secure green spaces that are insufficient in the city, serving as a key element of green infrastructure. Greening of artificial ground not only secures green spaces but also solves various urban environmental problems and contributes to improving the quality of life for urban residents. Greening of artificial ground is already perceived as a plan for environmental protection in the international agenda such as the United Nations

This paper was funded by the research project of Rural Development Administration (PJ0102522016).

Received: May 14, 2020, Revised: May 29, 2020, Accepted: June 4, 2020

First author: Myeong Il Jeong, jeongil@korea.kr, (D) https://orcid.org/0000-0002-6260-8666

*Corresponding author: Na Ra Jeong, jnr202@korea.kr, (D) https://orcid.org/0000-0002-0235-1424 
Framework Convention on Climate Change (UNFCCC) and Convention on Biological Diversity (CBD). Greening of artificial ground is forming green space by making the plantation base with artificially made soil deposits and drainage.

Green space with artificially made ground has extremely poor groundwork for plant growth compared to natural ground. A shallow plantation base is a poor environment for plants to grow and survive, and thus the plant species used was limited, while herbaceous flowers with short plants and low roots were mainly used. In particular, indeciduate sedums are suitable for growth even in a dry environment, have potential to maintain year-round greening, and are easily reproduced, thereby economically favorable (Cook-Patton and Bauerle, 2012; Dunnett and Kingsbury, 2008; Gurevitch et al., 1986; Terri et al., 1986; Vahdati et al., 2017). Recently, there is great interest in increasing the diversity of plant species used in the artificial ground system with focus on using herbaceous plants (Emilisson, 2008; MacDonagh et al., 2006; Schroll et al., 2009).

Herbaceous plants are suitable for the climate and natural features of Korea and have great adaptability, and thus can be regenerated and managed easily as a stable vegetation structure (Jeong et al., 2001). Moreover, they can cover the ground surface and have excellent ornamental value in leaves, flowers and fruits, and thus their utility value is increasing as gardening and landscaping plants. In particular, they have great aesthetic effects as the space of plantation can be changed by adjusting the flowering season by month every year, but constant management is required in order to maintain the aesthetic value, and thus they are not actually used much compared to their value. Studies on herbaceous plants are also focused on the ecological aspect such as plant growth, with insufficient research on use of herbaceous plants in terms of planting design. There were studies such as proposal of checklists to select herbaceous flowers for garden design (Sohn, 2012) and classification of growth characteristics such as petal color, plant height and flowering season of perennial herbaceous flowers for gardens (Sohn, 2013).

Studies on management of herbaceous flowers as plant materials are classified into plantation base, applied plant species, and irrigation. Studies were conducted on plantation base that directly intervenes with plant growth and exerts a significant effect (Choi et al., 2003; Huh et al., 2003; Park et al., 2010), and on selecting plants suitable for planting conditions (Cook-Patton and Bauerle, 2012; Durhman et al., 2007; Kang and Lee, 2005; Lee et al., 2007; Vahdati et al., 2017). There were also studies on irrigation cycle and amount of irrigation (Ahn et al., 2013; Bang et al., 2004; Ju et al., 2012; Kim et al., 2015; Kim et al., 2018; Lee et al., 2003; Nagase and Dunnett, 2010). Most studies on irrigation were on irritation time and frequency, as well as plant stress due to no irrigation.

This study is a basic research to come up with baseline data for irrigation management of herbaceous plants to increase their use as gardening and landscaping plant materials. Accordingly, this study set an adequate irrigation cycle by analyzing growth characteristics of plants based on soil water.

\section{Research Methods}

\section{Experimental plant}

For irrigation management of herbaceous flowers planted for urban greening, we selected the experimental plants to determine their growth characteristics depending on soil moisture content. The plants were those selected by the Ministry of Environment in Technology development for restoration natural ecosystem of urban artificial ground (Ministry of Environment, 2008) and Development of urban artificial ground ecosystem adaptation management technology (Ministry of Environment, 2016), which contribute to increasing species diversity and have high ornamental value. We used perennial herbaceous flowers such as Mukdenia rossii, Aquilegia japonica, Lilium lancifolium, Liriope platyphylla, Sedum kamtschaticum, Pachysandra terminalis, Ligularia stenocephala, Lythrum anceps, and Astilbe rubra in the experiment (Table 1).

\section{Method of experiment}

This study was conducted in a rain shelter greenhouse to analyze plant growth characteristics due to soil humidity. We classified the soil water content of the container into 
five conditions such as $20,15,10,5$, and $1 \%$ and formed the experimental group in early May. We selected plants with similar standards and planted them for 12 weeks in containers $(65 \times 75 \times 20 \mathrm{~cm})$ using nursery bed soil (coco peat $65-70 \%$, peat moss $8-12 \%$, vermiculite $10-14 \%$, zeolite $3-5 \%$, perlite $5-8 \%$, EC $0.65 \pm 0.3$, moisture holding ability

Table 1. Planted species used in the experiment

\begin{tabular}{ccc}
\hline No. & Scientific name & Flowering period \\
\hline 1 & Mukdenia rossii & May-June \\
2 & Astilbe rubra & June-August \\
3 & Aquilegia japonica & June-August \\
4 & Sedum kamtschaticum & August \\
5 & Liriope platyphylla & June-July \\
6 & Pachysandra terminalis & April-May \\
7 & Lilium lancifolium & May-July \\
8 & Ligularia stenocephala & July \\
9 & Lythrum anceps & September \\
\hline
\end{tabular}

$30-50 \%)$. We formed the experimental group with three replicates in the treatment condition of soil water content (Fig. 1). We irrigated the plants 3-4 times a week for 30 days so that they can take root in the containers. We also sprayed insecticides twice in summer to control unexpected occurrences of moth larvae.

Soil water content was measured using a soil water sensor (Delta T) every morning at 10 a.m. from 30 days after planting. The plants with lower measures than the treatment conditions such as soil water $20,15,10,5$, and $1 \%$ were presumed to have reached the irrigation point, and thus overhead irrigation was carried out $10 \mathrm{~L}$ each. Soil water content increased by $20 \%$ after $10 \mathrm{~L}$ of irrigation in the containers with the same soil as the experimental soil (Fig. 2). We measured the soil water content of the experimental plots every day and irrigated the plants when they fell short of the soil water content of the treatment plots, measured the irrigation frequency every month, and calculated the irrigation cycle.

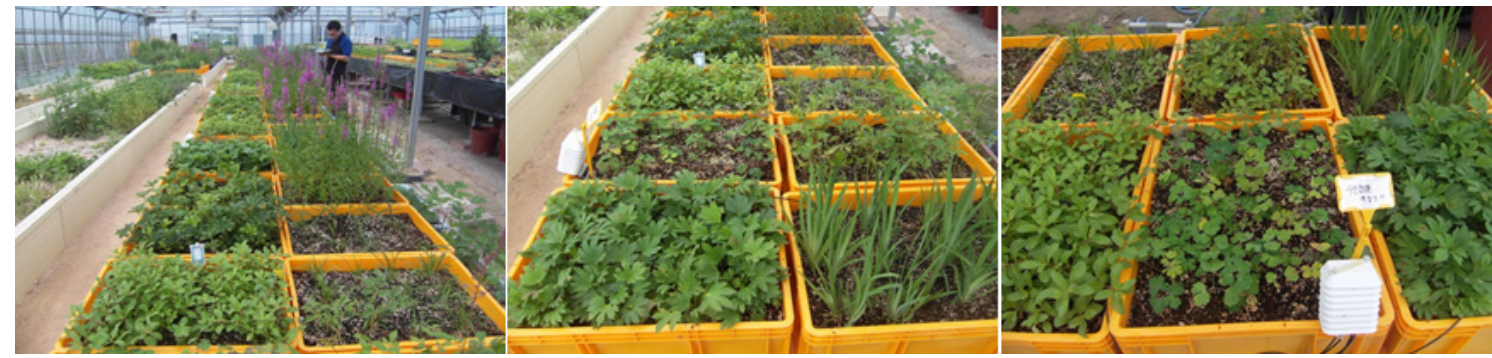

Fig. 1. Pictures taken 60 days after planting the experimental plants in the container.

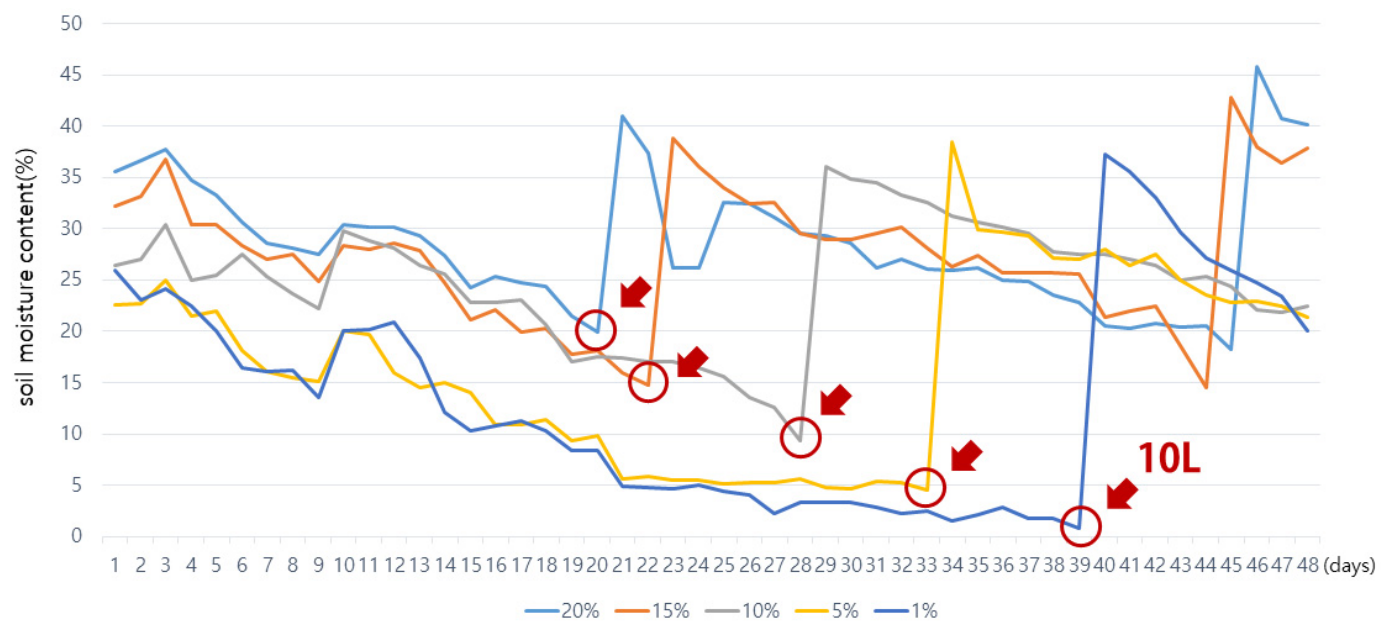

Fig. 2. Graph for explaining watering point (red circles and red arrows) according to soil moisture content(SMC). For example, in the graph, the irrigation time point of the $20 \%$ SMC is 19 days after, and the $1 \%$ SMC is 39 days after. 
Table 2. Survival rate of experimental plants by soil moisture content(SMC)

\begin{tabular}{|c|c|c|c|c|c|c|c|c|c|c|c|c|c|c|c|c|c|c|c|c|}
\hline \multirow{3}{*}{ Plant } & \multicolumn{20}{|c|}{ Survival rate $(\%)$} \\
\hline & \multicolumn{4}{|c|}{ SMC $20 \%$} & \multicolumn{4}{|c|}{ SMC $15 \%$} & \multicolumn{4}{|c|}{ SMC $10 \%$} & \multicolumn{4}{|c|}{ SMC 5\% } & \multicolumn{4}{|c|}{ SMC $1 \%$} \\
\hline & July & August & Sep & Oct & July & August & Sep & Oct & July & August & Sep & Oct & July & August & Sep & Oct & July & August & Sep & Oct \\
\hline Mukdenia rossii & 100 & 100 & 100 & 100 & 100 & 100 & 100 & 100 & 100 & 100 & 100 & 100 & 100 & 100 & 100 & 100 & 100 & 100 & 100 & 100 \\
\hline Astilbe rubra & 100 & 100 & 100 & 100 & 100 & 100 & 100 & 100 & 100 & 100 & 100 & 100 & 100 & 100 & 100 & 100 & 100 & 100 & 100 & 100 \\
\hline Aquilegia japonica & 100 & 100 & 100 & 100 & 100 & 100 & 100 & 100 & 100 & 100 & 100 & 100 & 100 & 100 & 100 & 100 & 100 & 100 & 100 & 100 \\
\hline Sedum kamtschaticum & 100 & 100 & 100 & 100 & 100 & 100 & 100 & 100 & 100 & 100 & 100 & 100 & 100 & 100 & 100 & 100 & 100 & 100 & 100 & 100 \\
\hline Liriope platyphylla & 100 & 100 & 100 & 100 & 100 & 100 & 100 & 100 & 100 & 100 & 100 & 100 & 100 & 100 & 100 & 100 & 100 & 100 & 100 & 100 \\
\hline Pachysandra terminalis & 100 & 100 & 100 & 100 & 100 & 100 & 100 & 100 & 100 & 100 & 100 & 100 & 100 & 100 & 100 & 100 & 100 & 100 & 100 & 100 \\
\hline Lilium lancifolium & 83.3 & 50.0 & 16.7 & 0 & 100 & 100 & 8.3 & 8.3 & 100 & 100 & 8.3 & 0 & 100 & 83.3 & 0 & 0 & 100 & 50 & 0 & 0 \\
\hline Ligularia stenocephala & 100 & 100 & 91.7 & 75 & 100 & 100 & 100 & 100 & 100 & 100 & 91.7 & 91.7 & 100 & 100 & 100 & 100 & 100 & 100 & 83.3 & 83.3 \\
\hline Lythrum anceps & 100 & 100 & 100 & 100 & 100 & 100 & 100 & 100 & 100 & 100 & 100 & 100 & 100 & 100 & 100 & 100 & 100 & 100 & 100 & 100 \\
\hline
\end{tabular}

\section{Method of survey and analysis}

We investigated the growth conditions of plants in each treatment plot to determine adequate soil water content for each plant. Methods to determine plant growth conditions include surveying growth conditions of the crowns, stems, leaves, flowers and fruits on the aerial part and surveying growth conditions of the roots in the underground part (Kim, 2007). This study investigated plant height as well as fresh weight and dry weight of roots by treatment condition and calculated relative growth amount to compare plant growth amount for 5 months based on monthly plant height.

Plant height was determined by measuring from ground surface to the tallest part of the plant from early June, 30 days after plantation, to October at 30-day intervals. Relative growth amount was calculated by dividing growth variation (difference between growth amount at the end of the experiment and growth amount at the beginning of plantation) by the number of growing days (until the end of the experiment after planting). We measured plant height until October, and then washed the roots and removed soil from them in November, after which we removed moistness and measured fresh weight. Then we measured dry weight after completely drying them. Dry weight was measured after drying the plants for 72 hours at $70^{\circ} \mathrm{C}$ using a dryer.

Data measured from each treatment plot were processed using SPSS 25 Program to analyze the means of plant height and fresh weight by month and treatment plot. Moreover, along with analysis of variance, we analyzed Duncan's test (DMRT) based on the $p$-value of .05 or be- low, thereby assessing significance due to number of growing days and soil water content. To predict the irrigation point suitable for growth characteristics of each plant, we also conducted a regression analysis with growth characteristics as the dependent variable and soil water content as the independent variable.

\section{Results and Discussion}

\section{Growth conditions of aerial parts}

We analyzed the growth conditions from June and October by treatment plot in the irrigation area and found that plants other than Lilium lancifolium and Ligularia stenocephala showed constant growth without withering. Lilium lancifolium showed poor growth after flowering in July, and the aerial part was almost withered in all treatment plots since September. Ligularia stenocephala also showed poor growth in some treatment plots since September (Table 2).

We measured plant height of 12 entities in each treatment plot at 30-day intervals after planting to determine the growth conditions of the aerial part. The result of analyzing growth characteristics of each plant shows that most plants continued to grow until flowering, after which growth tended to decrease (Fig. 3). Mukdenia rossii showed constant growth until September at $15 \%$ soil water content and then slowed down and showed poor growth in other treatment plots. Astilbe rubra showed excellent growth characteristics at $15 \%$ compared to other treatment plots, growing rapidly until August and then slowing down. 


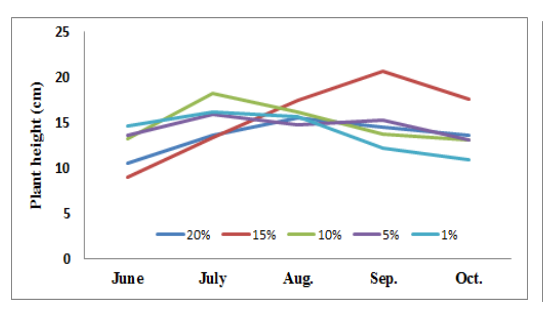

Mukdenia rossii

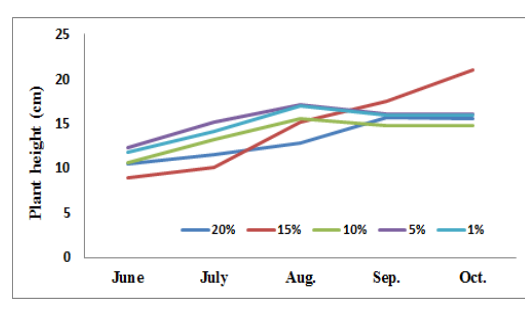

Sedum kamtschaticum

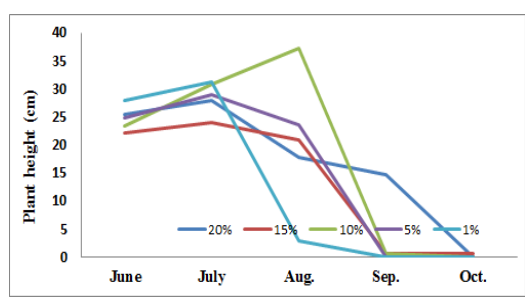

Lilium lancifolium

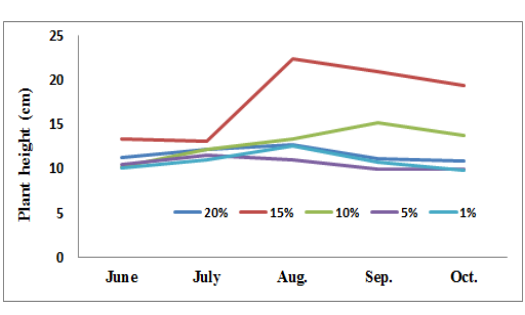

Astilbe rubra

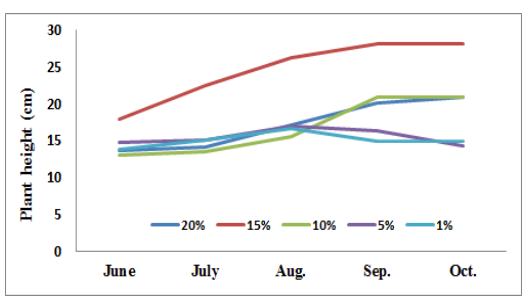

Liriope platyphylla

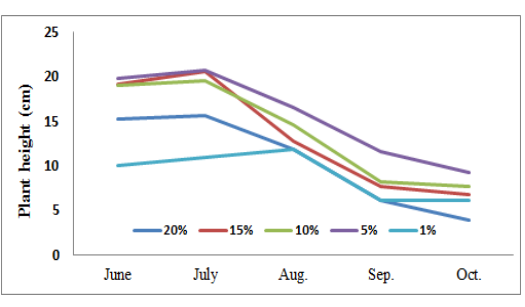

Ligularia stenocephala

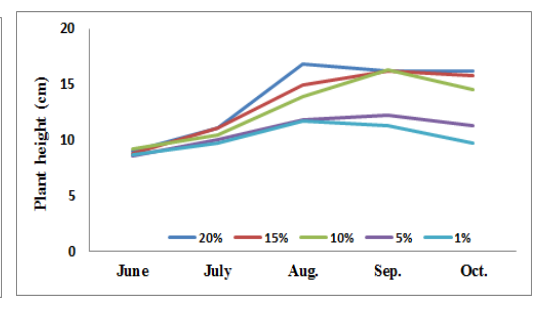

Aquilegia japonica

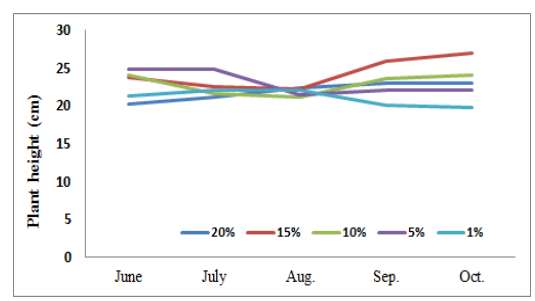

Pachysandra terminalis

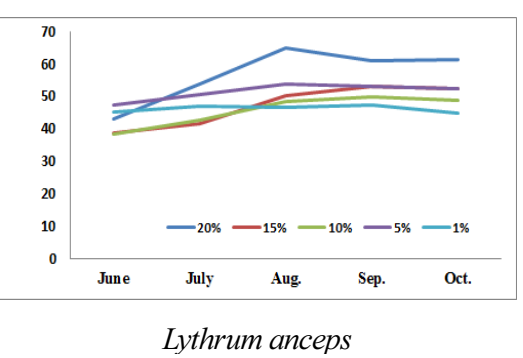

Fig. 3. The growth patterns of plant height by soil moisture content. Growth characteristics are average values of 12 individuals by month.

Aquilegia japonica tended to grow until August and then slowed down, showing excellent growth at $20 \%$. Sedum kamtschaticum started to slow down in growth starting from August, but showed constant growth at $15 \%$ soil water content. Liriope platyphylla had higher plant height at $15 \%$ compared to other treatment plots and tended to show constant growth until September. Pachysandra terminalis showed insufficient growth during the experiment and did not show much change in growth in each treatment plot.

Lilium lancifolium seemed to have stopped growing since flowering, almost withering away since July and August. Ligularia stenocephala showed a difference in early growth amount according to soil water content compared to other plants. A relatively big amount of soil water seems to be required at the initial stage of growth for Ligularia stenocephala. Plant height decreased in all treatment plots after July, and the reduction speed was slower at 5\% than other treatment plots. Lythrum anceps grew until August and slowed down, and was higher at $20 \%$ compared to other treatment plots. Plants other than Lilium lancifolium and Ligularia stenocephala maintained consistent plant height until October and thus are effective in maintaining landscape. Lilium lancifolium and Ligularia stenocephala might be more useful to plant with other plants that can supplement them after flowering rather than planting them alone.

An analysis on the time series change of plant height showed that Ligularia stenocephala showed high growth at 5\%, Lilium lancifolium and Astilbe rubra at 10\%, and Mukdenia rossii, Aquilegia japonica, and Liriope platyphylla at $15 \%$. Pachysandra terminalis maintained similar growth conditions regardless of soil water content, and Lythrum anceps maintained growth at $20 \%$ and higher. This showed that soil water content to maintain suitable growth conditions varied among plants.

Since growth speed and size vary among plants, we comparatively analyzed the experimental plants based on relative growth amount (Table 3). The analysis on relative growth amount of plant height showed that Mukdenia ros- 
Table 3. One-way ANOVA of relative growth of height by soil moisture content(SMC)

\begin{tabular}{|c|c|c|c|c|c|c|}
\hline \multirow{2}{*}{ Species } & \multicolumn{5}{|c|}{ Relative growth of height $(\mathrm{cm} /$ day $)$} & \multirow{2}{*}{$\mathrm{F}(p$-value $)$} \\
\hline & SMC $20 \%$ & SMC $15 \%$ & SMC $10 \%$ & SMC 5\% & SMC $1 \%$ & \\
\hline Mukdenia rossii & $0.03 \pm 0.01 \mathrm{~b}^{\mathrm{z}}$ & $0.07 \pm 0.02 \mathrm{a}$ & $0.00 \pm 0.00 \mathrm{c}$ & $-0.01 \pm 0.02 \mathrm{c}$ & $-0.03 \pm 0.02 \mathrm{~d}$ & $67.99(<.001)$ \\
\hline Astilbe rubra & $0.06 \pm 0.01 \mathrm{a}$ & $0.06 \pm 0.01 \mathrm{a}$ & $0.04 \pm 0.01 \mathrm{~b}$ & $0.02 \pm 0.01 \mathrm{c}$ & $0.01 \pm 0.01 \mathrm{~d}$ & $72.916(<.001)$ \\
\hline Aquilegia japonica & $0.00 \pm 0.02 \mathrm{c}$ & $0.05 \pm 0.02 \mathrm{a}$ & $0.00 \pm 0.02 \mathrm{c}$ & $0.00 \pm 0.01 \mathrm{c}$ & $0.03 \pm 0.02 \mathrm{~b}$ & $21.49(<.001)$ \\
\hline Sedum kamtschaticum & $0.04 \pm 0.01 \mathrm{~b}$ & $0.10 \pm 0.01 \mathrm{a}$ & $0.03 \pm 0.01 \mathrm{~b}$ & $0.03 \pm 0.02 \mathrm{~b}$ & $0.04 \pm 0.02 \mathrm{~b}$ & $40.93(<.001)$ \\
\hline Liriope platyphylla & $0.06 \pm 0.01 \mathrm{~b}$ & $0.09 \pm 0.01 \mathrm{a}$ & $0.07 \pm 0.01 \mathrm{~b}$ & $0.00 \pm 0.01 \mathrm{~d}$ & $0.01 \pm 0.02 \mathrm{c}$ & $102.42(<.001)$ \\
\hline Pachysandra terminalis & $0.02 \pm 0.01 \mathrm{a}$ & $0.03 \pm 0.01 \mathrm{a}$ & $0.00 \pm 0.03 \mathrm{~b}$ & $-0.02 \pm 0.02 \mathrm{c}$ & $-0.01 \pm 0.01 \mathrm{c}$ & $20.85(<.001)$ \\
\hline Lilium lancifolium & $-0.09 \pm 0.05 \mathrm{~b}$ & $-0.10 \pm 0.04 b$ & $-0.09 \pm 0.03 b$ & $-0.09 \pm 0.03 b$ & $-0.03 \pm 0.02 \mathrm{a}$ & $7.26(<.001)$ \\
\hline Ligularia stenocephala & $0.15 \pm 0.05 \mathrm{a}$ & $0.11 \pm 0.07 \mathrm{~b}$ & $0.09 \pm 0.04 \mathrm{~b}$ & $0.04 \pm 0.04 \mathrm{c}$ & $0.00 \pm 0.02 \mathrm{~d}$ & $20.01(<.001)$ \\
\hline
\end{tabular}

Note. Values are mean \pm SD. Relative growth of height $=($ Height at 150 days - Height at 30 days $) / 150$ days.

${ }^{\mathrm{z}}$ Means followed by same letter within the row are not significantly different at $5 \%$ level.

Table 4. One-way ANOVA of root fresh weight by soil moisture content(SMC)

\begin{tabular}{lcccccc}
\hline \multirow{2}{*}{ Species } & \multicolumn{5}{c}{ Root fresh weight $(\mathrm{g})$} & \multicolumn{2}{c}{$\mathrm{F}(p$-value $)$} \\
\cline { 2 - 5 } & SMC $20 \%$ & SMC $15 \%$ & SMC $10 \%$ & SMC 5\% & SMC 1\% & \\
\hline Mukdenia rossii & $50.2 \pm 3.0 \mathrm{~b}^{\mathrm{z}}$ & $74.2 \pm 4.2 \mathrm{a}$ & $56.3 \pm 4.9 \mathrm{~b}$ & $57.5 \pm 4.7 \mathrm{~b}$ & $81.7 \pm 6.8 \mathrm{a}$ & $7.404(<.001)$ \\
Astilbe rubra & $46.1 \pm 4.4 \mathrm{~b}$ & $81.1 \pm 11.6 \mathrm{a}$ & $46.0 \pm 4.5 \mathrm{~b}$ & $40.1 \pm 5.7 \mathrm{~b}$ & $35.9 \pm 1.9 \mathrm{~b}$ & $7.674(<.001)$ \\
Aquilegia japonica & $15.2 \pm 1.5 \mathrm{ab}$ & $11.2 \pm 1.5 \mathrm{~b}$ & $11.9 \pm 1.2 \mathrm{~b}$ & $18.9 \pm 2.0 \mathrm{a}$ & $19.9 \pm 3.0 \mathrm{a}$ & $4.109(.006)$ \\
Sedum kamtschaticum & $53.8 \pm 4.1 \mathrm{NS}$ & $49.3 \pm 5.4 \mathrm{NS}$ & $46.3 \pm 5.7 \mathrm{NS}$ & $68.1 \pm 10.5 \mathrm{NS}$ & $42.7 \pm 5.8 \mathrm{NS}$ & $2.195(.082)$ \\
Liriope platyphylla & $30.8 \pm 3.9 \mathrm{c}$ & $47.6 \pm 6.8 \mathrm{ab}$ & $38.7 \pm 5.2 \mathrm{bc}$ & $40.1 \pm 3.7 \mathrm{bc}$ & $57.5 \pm 4.3 \mathrm{a}$ & $4.159(.005)$ \\
Pachysandra terminalis & $83.6 \pm 6.0 \mathrm{abc}$ & $76.6 \pm 6.2 \mathrm{bc}$ & $89.2 \pm 6.9 \mathrm{ab}$ & $101.1 \pm 8.2 \mathrm{a}$ & $67.7 \pm 5.6 \mathrm{c}$ & $3.599(.011)$ \\
Lilium lancifolium & $8.4 \pm 0.7 \mathrm{~b}$ & $5.8 \pm 1.0 \mathrm{~b}$ & $12.2 \pm 1.9 \mathrm{a}$ & $12.7 \pm 1.0 \mathrm{a}$ & $12.7 \pm 1.3 \mathrm{a}$ & $6.291(<.001)$ \\
Ligularia stenocephala & $5.5 \pm 0.8 \mathrm{~b}$ & $14.9 \pm 2.9 \mathrm{a}$ & $15.3 \pm 2.9 \mathrm{a}$ & $18.0 \pm 3.4 \mathrm{a}$ & $19.8 \pm 3.3 \mathrm{a}$ & $3.758(.009)$ \\
Lythrum anceps & $46.6 \pm 5.6 \mathrm{NS}$ & $55.2 \pm 5.3 \mathrm{NS}$ & $63.9 \pm 7.2 \mathrm{NS}$ & $68.2 \pm 9.7 \mathrm{NS}$ & $71.1 \pm 12.0 \mathrm{NS}$ & $1.434(.235)$ \\
\hline
\end{tabular}

Note. Values are mean \pm SD.

${ }^{\mathrm{z}}$ Means followed by same letter within the row are not significantly different at $5 \%$ level and NS means not significant.

sii, Aquilegia japonica, Sedum kamtschaticum, and Liriope platyphylla had high relative growth amount at $15 \%$. Unlike other plants, Ligularia stenocephala showed high relative growth amount at 1\%, and Lythrum anceps at 20\%. Astilbe rubra and Pachysandra terminalis showed similar growth characteristics at $20 \%$ and $15 \%$, but considering the irrigation cycle, it would be enough to start irrigation at $15 \%$.

\section{Growth conditions of underground parts}

\section{Fresh weight}

As a result of measuring root weight of plants used in the experiment, it was found that root weight varied among plants depending on soil water content. The irrigation affecting root weight was as follows (Table 4). Mukdenia rossii, Aquilegia japonica, Liriope platyphylla, Lilium lancifolium, and Ligularia stenocephala were heaviest at $1 \%$, Astilbe rubra at 15\%, Sedum kamtschaticum and Pachysandra terminalis at 5\%. As a result of conducting analysis of variance on the difference in root weight by irrigation, it was found that plants except Sedum kamtschaticum and Lythrum anceps showed a statistically significant difference in root weight depending on the treatment. Mukdenia rossii showed active root development at 15\% and 1\%, Astilbe rubra at 15\%, Aquilegia japonica and Liriope platyphylla at 1\%, Pachysandra terminalis at 5\%, Lilium lancifolium at 1, 5, 10\%, and Ligularia stenocephala 
at all irrigations except 20\%. Nagase and Dunnett (2010) explained that root weight increased due to frequent irrigation. In other words, sufficient irrigation may have affected root development. Based on the analysis of root weight alone, it seems Mukdenia rossii, Aquilegia japonica, Liriope platyphylla, Lilium lancifolium, and Ligularia stenocephala must maintain at least 1\% soil water content, Astilbe rubra 15\%, and Pachysandra terminalis 5\%.

\section{Dry weight}

As a result of analyzing dry weight according to each soil water content, it was found that Aquilegia japonica, Liriope platyphylla, Lilium lancifolium, and Ligularia stenocephala showed insignificant growth difference due to soil water content. Sedum kamtschaticum, Pachysandra terminalis, and Lythrum anceps showed high growth at
$5 \%$ soil water content, Mukdenia rossii at $10 \%$, and Astilbe rubra at $15 \%$ (Fig. 4).

\section{Irrigation point}

Irrigation was performed at the point of reaching soil water content, and Table 5 shows the frequency of irrigation per month. The monthly irrigation frequency from July to October showed that all plants had highest irrigation frequency in July, which decreased upon approaching October. This explains that intensive irrigation management is required in summer to plant herbaceous flowers. Lythrum anceps showed higher irrigation frequency in all plots compared to other plants, indicating that they require a greater amount of irrigation than others. On the other hand, Liriope platyphylla and Ligularia stenocephala required relatively

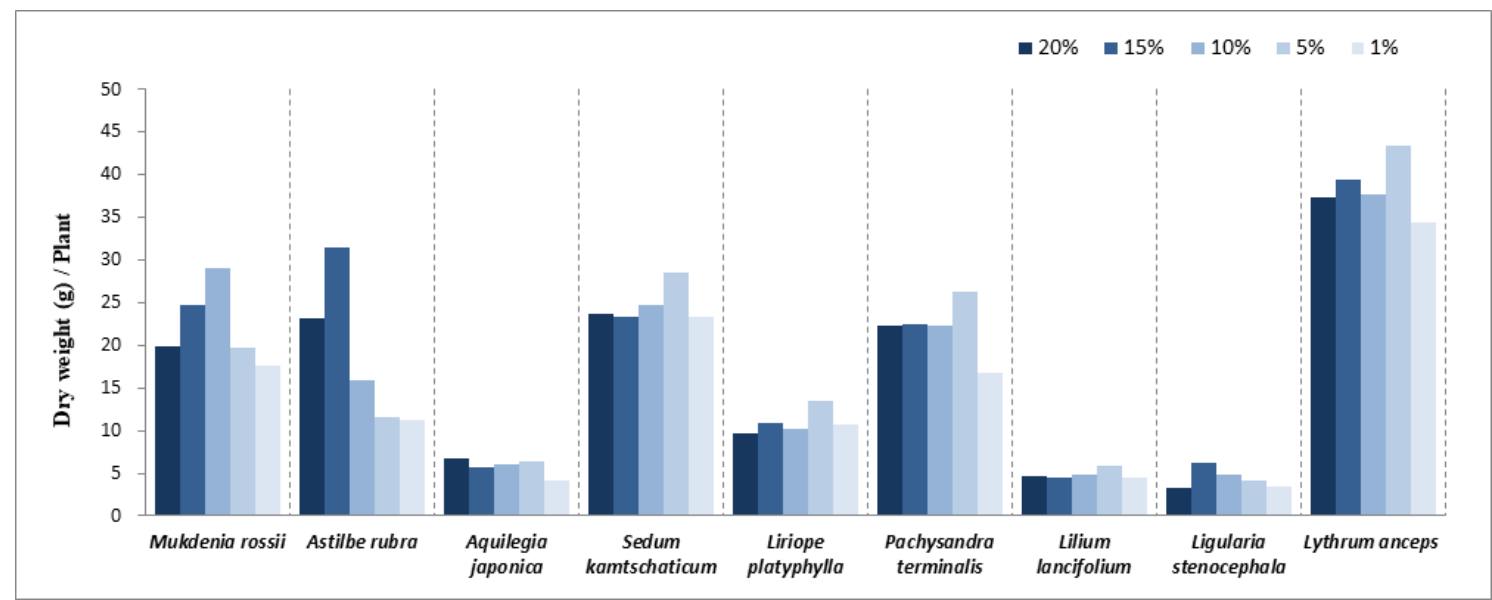

Fig. 4. Dry weight of plant by soil moisture content.

Table 5. Frequency of irrigation per month to reach soil moisture content

\begin{tabular}{|c|c|c|c|c|c|c|c|c|c|c|c|c|c|c|c|c|c|c|c|c|}
\hline \multirow{3}{*}{ Plant } & \multicolumn{20}{|c|}{ Irrigation frequency } \\
\hline & \multicolumn{4}{|c|}{ SMC $20 \%$} & \multicolumn{4}{|c|}{ SMC $15 \%$} & \multicolumn{4}{|c|}{ SMC $10 \%$} & \multicolumn{4}{|c|}{ SMC 5\% } & \multicolumn{4}{|c|}{ SMC $1 \%$} \\
\hline & July & August & Sep & Oct & July & August & Sep & Oct & July & August & Sep & Oct & July & August & Sep & Oct & July & August & Sep & Oct \\
\hline Mukdenia rossii & 4 & 2 & 2 & 1 & 5 & 2 & 2 & 1 & 3 & 1 & 2 & 1 & 4 & 1 & 2 & 0 & 3 & 1 & 2 & 0 \\
\hline Astilbe rubra & 3 & 3 & 2 & 1 & 3 & 2 & 2 & 1 & 3 & 1 & 2 & 0 & 2 & 1 & 2 & 1 & 2 & 1 & 3 & 1 \\
\hline Aquilegia japonica & 4 & 3 & 3 & 0 & 4 & 2 & 3 & 0 & 2 & 2 & 2 & 1 & 2 & 1 & 2 & 0 & 2 & 0 & 1 & 0 \\
\hline Sedum kamtschaticum & 5 & 1 & 2 & 1 & 3 & 2 & 2 & 1 & 4 & 2 & 2 & 1 & 3 & 1 & 1 & 1 & 1 & 1 & 1 & 0 \\
\hline Liriope platyphylla & 2 & 2 & 2 & 0 & 3 & 1 & 2 & 0 & 2 & 1 & 2 & 0 & 2 & 1 & 1 & 1 & 2 & 1 & 1 & 0 \\
\hline Pachysandra terminalis & 4 & 2 & 1 & 1 & 2 & 2 & 1 & 1 & 3 & 1 & 2 & 0 & 3 & 2 & 1 & 0 & 1 & 1 & 1 & 1 \\
\hline Lilium lancifolium & 3 & 1 & 2 & 0 & 3 & 1 & 2 & 0 & 2 & 1 & 2 & 0 & 3 & 1 & 1 & 0 & 2 & 0 & 1 & 1 \\
\hline Ligularia stenocephala & 2 & 2 & 2 & 1 & 3 & 2 & 2 & 1 & 2 & 2 & 1 & 0 & 1 & 1 & 1 & 0 & 2 & 1 & 1 & 1 \\
\hline Lythrum anceps & 7 & 4 & 4 & 2 & 7 & 4 & 4 & 1 & 6 & 3 & 4 & 0 & 4 & 4 & 4 & 1 & 5 & 3 & 3 & 1 \\
\hline
\end{tabular}




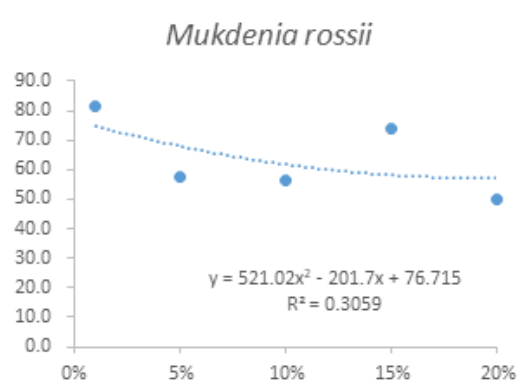

Sedum kamtschaticum

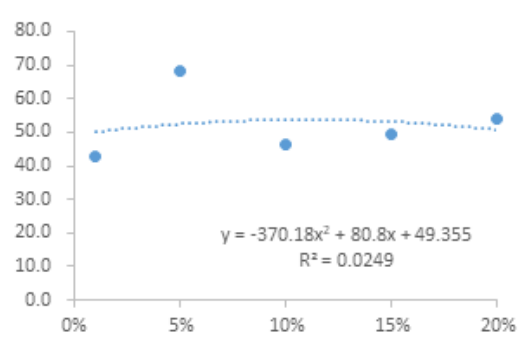

Lilium Iancifolium

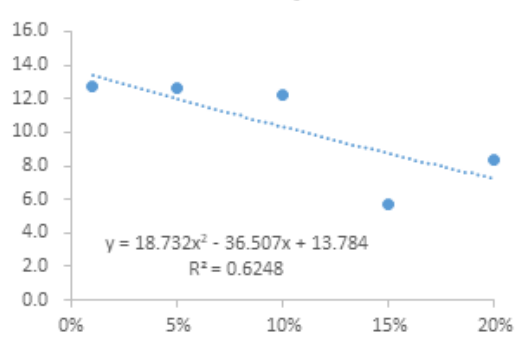

Astilbe rubra

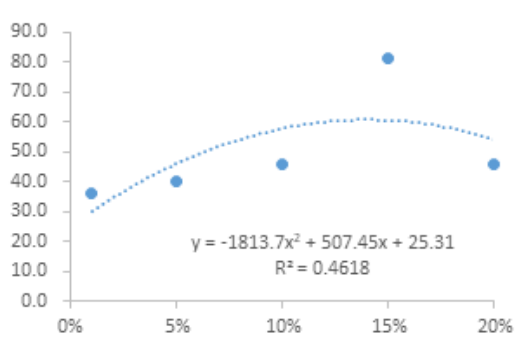

Liriope platyphylla

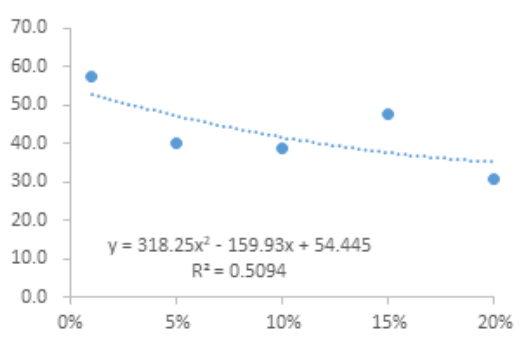

Ligularia stenocephala

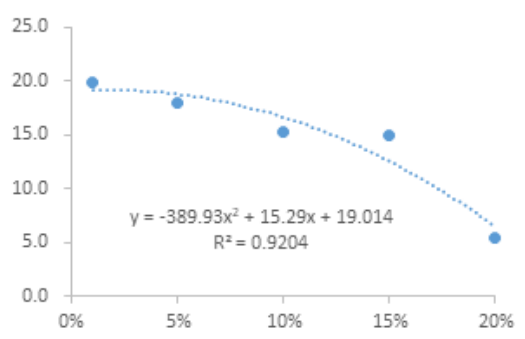

Aquilegia japonica

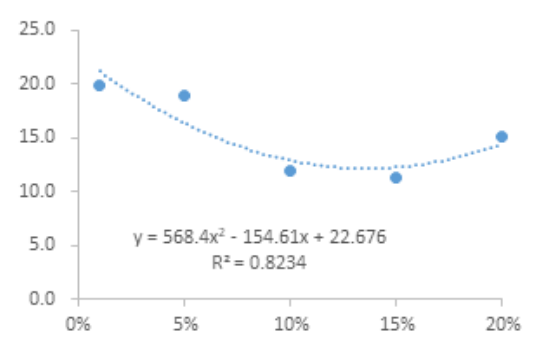

Pachysandra terminalis

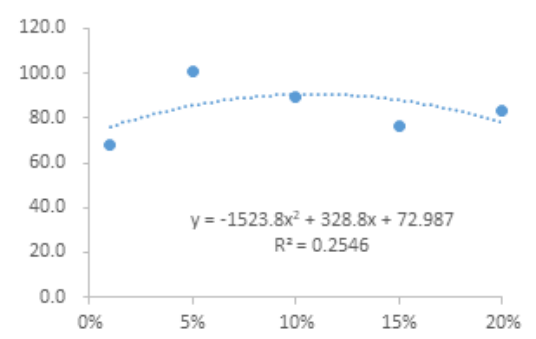

Lythrum anceps

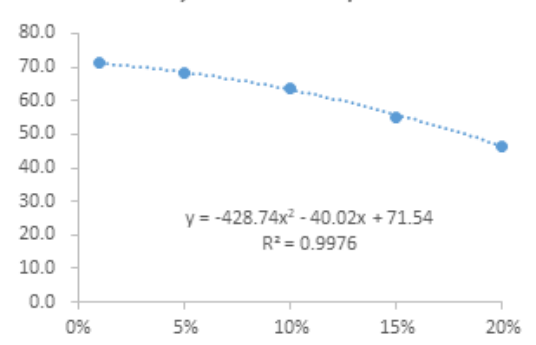

Fig. 5. Prediction of irrigation point of each plant based on fresh weight of plants. In the graph, the $x$-axis is soil moisture content(\%) and the $\mathrm{y}$-axis is root fresh weight(g).

less irrigation.

We predicted the irrigation point based on fresh weight of plants in each treatment plot using regression analysis (Fig. 5). The results of analyzing the optimum irrigation point for each plant are as follows: Mukdenia rossii 19.4\%, Astilbe rubra 14\%, Aquilegia japonica 13.0\%, Sedum kamtschaticum 10.9\%, Liriope platyphylla 25.1\%, Pachysandra terminalis $10.8 \%$, Ligularia stenocephala $2.0 \%$, and Lythrum anceps 5\%. By determining coherence of the regression equation with the adjusted R-squared, it was found that Aquilegia japonica, Ligularia stenocephala, and Lythrum anceps showed relatively small prediction error, indicating that it is desirable to manage irrigation based on the predicted irrigation point.

As a result of adjusting soil water of irrigation point at $20,15,10,5$, and $1 \%$ in the containers, Astilbe rubra,
Lilium lancifolium, and Lythrum anceps showed temporary wilting phenomena at $1 \%$ soil water, but at $5 \%$ or higher soil water, there was no problem with survival despite poor growth. An analysis of suitable irrigation points based on growth information such as plant height and fresh weight showed that $15 \%$ was suitable for Mukdenia rossii, Astilbe rubra, Aquilegia japonica, and Sedum kamtschaticum, 10\% for Pachysandra terminalis and Lilium lancifolium, and 5\% for Ligularia stenocephala, Lythrum anceps, and Liriope platyphylla. With the lowest irrigation point at 5\% soil water in using artificial ground, irrigation must be performed every 8 days for Lythrum anceps, every 14 days for Mukdenia rossii, every 17 days for Astilbe rubra and Sedum kamtschaticum, and every 20 days for Aquilegia japonica, Liriope platyphylla, Pachysandra terminalis, and Lilium lancifolium (Fig. 6). 


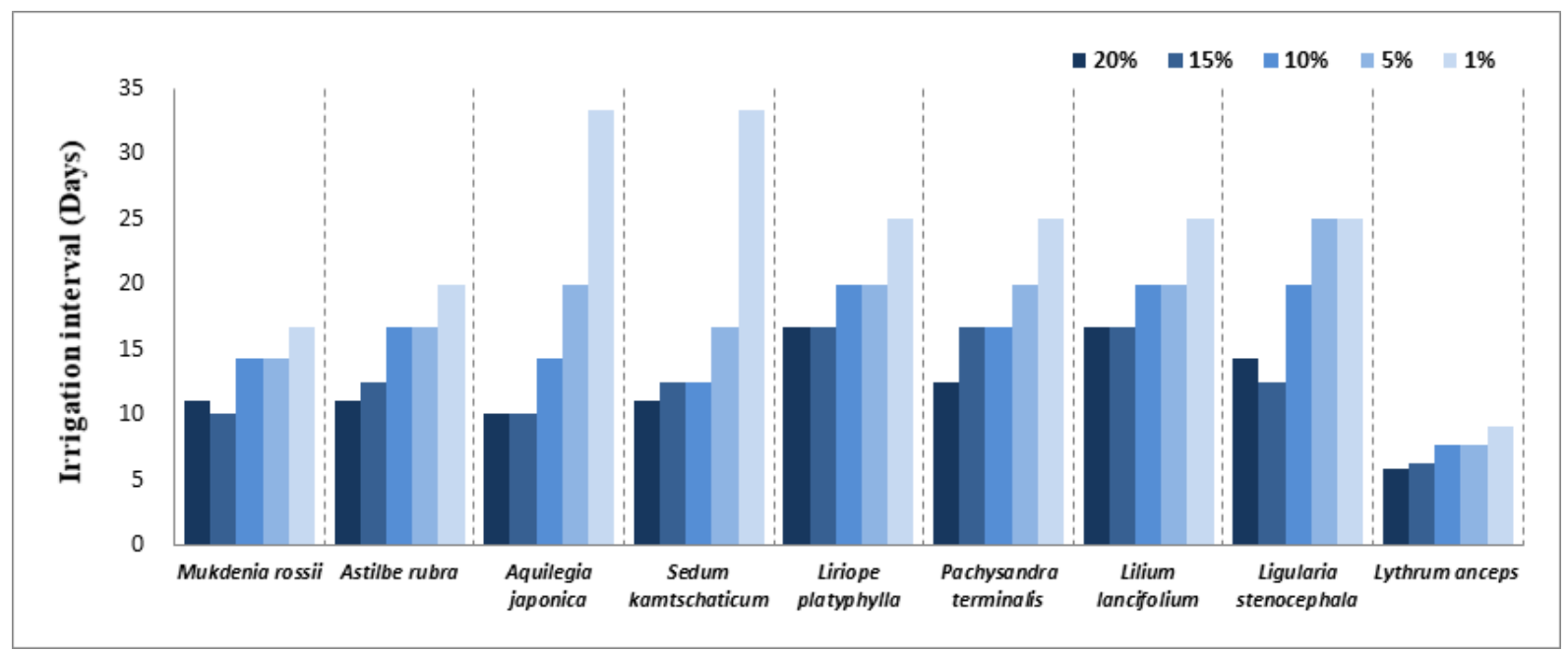

Fig. 6. Irrigation intervals by soil moisture content.

\section{Conclusion}

This study is conducted to analyze the growth characteristics of herbaceous plants according to soil water in planting conditions with limited soil depth and provide guidelines for irrigation management. As a result of investigating growth conditions of aerial parts according to soil water content in 9 species of herbaceous plants, most plants turned out to show constant growth until flowering, after which growth slowed down, and soil water content turned out to affect growth speed. Considering statistical significance, relative growth amount of plant height was high at $15 \%$ for Mukdenia rossii, Astilbe rubra, Aquilegia japonica, Sedum kamtschaticum, Liriope platyphylla, and Pachysandra terminalis, 1\% for Ligularia stenocephala, and $20 \%$ for Lythrum anceps. Considering fresh weight of underground parts, Astilbe rubra was heavy at $15 \%$, Sedum kamtschaticum and Pachysandra terminalis at 5\%, and other plants at $1 \%$. Root development affects plant growth and is thus a key factor in sustainability of growth for herbaceous plants. Considering overall growth characteristics of aerial and underground parts, the suitable soil water content and irrigation cycle for each herbaceous plants are as follows. Mukdenia rossii and Astilbe rubra show favorable growth of aerial and development of underground parts at $15 \%$, and the predicted irrigation point is $19.4 \%$ and $14.0 \%$, but $15 \%$ is suitable considering econom- ic feasibility or convenience, and the irrigation cycle is 10 days and 13 days. Sedum kamtschaticum and Pachysandra terminalis show favorable growth of aerial parts at $15 \%$ and development of underground parts at $5 \%$, and the predicted irrigation point is $10.9 \%$ and $10.8 \%$. $10 \%$ is also adequate considering growth of both aerial and underground parts, and irrigation cycle is 13 days and 17 days. Aquilegia japonica and Liriope platyphylla showed favorable growth of aerial parts at $15 \%$ and underground parts at $1 \%$, and the predicted irrigation point is $13 \%$ and $25 \%$. However, $15 \%$ is suitable considering statistical significance, and the irrigation cycle is 10 days and 17 days. Ligularia stenocephala shows favorable development of aerial and underground parts at both $1 \%$. The irrigation point is measured as $2.0 \%$ and thus irrigation must be performed at $1 \%$ soil water in a cycle of 25 days. Lythrum anceps showed favorable growth of aerial parts at $20 \%$ and underground parts at $1 \%$, and the predicted irrigation point is $4.7 \%$. Thus, irrigation must be performed at $5 \%$ at a cycle of 8 days.

This study used limited plants in the experiment and analyzed only the growth characteristics. Moreover, there were growth differences in the process of plant supply even though plants with similar sizes and standards were selected. A more suitable irrigation cycle can be set by implementing the experimental plants in limited planting conditions, and it would be possible to provide guidelines to plan planting design with focus on plants that have similar irrigation cycles. 


\section{References}

Ahn, G.Y., S.W. Han, and E.H. Lee. 2013. Soil moisture reduction pattern and that influences for plants in the condition of no rainfall and no irrigation. Korean J. Environ. Ecol. 27(6):745-756.

Bang, K.J., J.H. Ju, and S.H. Kim. 2004. Effects of soil depth and irrigation period on some of the native plants in an artificial substrate of roof garden. J. Korean Environ. Restor. Reveg. Technol. 7(6):75-83.

Choi, H.S., S.Y. Hong, K.G. Kim, B.E. Yang, and W.Y. Oh. 2003. A study of management method of planted plants and invasive plants through monitoring on rooftop garden "Choroktteul"in Seoul City hall. J. Korean Inst. Landsc. Archit. 31(3):114-124.

Cook-Patton, S.C. and T.L. Bauerle. 2012. Potential benefits of plant diversity on vegetated roofs: A literature review. J. Environ. Manag. 106:85-92 https://doi.org/10.1016/j.jenvman.2012.04.003

Dunnett, N. and N. Kingsbury. 2008. Planting green roofs and living walls (2nd ed.). Portland, OR: Timber Press.

Durhman, A.K., D.B. Rowe, and C.L. Rugh. 2007. Effect of substrate depth on initial growth, coverage and survival of 25 succulents green roof plant taxa. HortScience 42(3):588-595. https://doi.org/10.21273/HORTSCI.42. 3.588

Emilsson, T. 2008. Vegetation development on extensive vegetated green roofs: influence of substrate composition, establishment method and species mix. Ecol. Eng. 33(3-4): 265-277. https://doi.org/10.1016/j.ecoleng.2008.05.005

Gurevitch, J., J.A. Teeri, and A.M. Wood. 1986. Differentiation among populations of Sedum wrightii (Crassulaceae) in response to limited water availability: water relations, $\mathrm{CO} 2$ assimilation, growth and survivorship. Oecologia 70:198-204.

Huh, G.Y., I.H. Kim, and H.C. Kang. 2003. Effects of artificial substrate type, soil depth, and drainage type on the growth of sedum sarmentosum grown in a shallow green rooftop system. J. Korean Inst. Landsc. Archit. 31(2):102-112.

Jeong, J.H., I.S. Han, and S.H. Lee. 2001. Effects of several korean native wild perennial flowers and kinds of basal sheets on sod formation. J. Korean Environ. Restor. Reveg. Technol. 4(4):19-24.
Ju, J.H., G.T. Bae, W.T. Kim, and Y.H. Yoon 2012. Computation of irrigation interval and amount as affected by growing substrate and soil depth planted with Zoysia japonica in green roof during a dry summer. J. Environ. Sci. 21(3):289-296. https://doi.org/10.5322/JES.2012.2 1.3.289

Kang, K.Y. and E.H. Lee. 2005. The study on native plants and planting soil for extensive rooftop greening. J. Korean Environ. Restor. Reveg. Technol. 8(4):23-31.

Kim, D.G. 2007. Roots characteristics of Zelkova serrata Mkino. after replanting on the reclaimed land from the sea: On the root structure and spatial distribution of fine root phytomass. J. Korean Inst. Landsc. Archit. 35(5): 46-55.

Kim, D.Y., H.R. Park, Y.M. Ha, and K.S. Ryu. 2018. Effect of irrigation on growth characteristics of herb plants on a green rooftop area. J. Korean Inst. Landsc. Archit. 46(1): 96-105. https://doi.org/10.9715/KILA.2018.46.1.096

Kim, S.M., S.W. Han, H.K. Jang, J.S. Kim, and M.I. Jeong. 2015. Characteristics of soil moisture rate for optimal growth conditions on greenroof plants. Korean J. Environ. Ecol. 29(6):947-951. https://doi.org/10.13047/KJEE.201 5.29.6.947

Lee, E.H., E.J. Cho, M.Y. Park, D.W. Kim, and S.W. Jang. 2007. Selecting plants for the extensive rooftop greening based on herbal plants. J. Korean Environ. Restor. Reveg. Technol. 10(2):84-96.

Lee, J.P., I.S. Han, Y.K. Joo, W.J. Yun, J.I. Jeong, C.H. Jang, and D.H. Kim. 2003. Rootzone profile, trickle irrigation system and turfgrass species for roof turf garden. Weed Turfgrass Sci. 17(4):155-163.

MacDonagh, L.P., N.M. Hallyn, and S. Rolph. May, 2006. Midwestern USA plant communities + Design $=$ Bedrock bluff prairie greenroofs. Proceedings of 4th North American Green Roof Conference: Greening Rooftops for Sustainable Communities. Boston, MA.

Ministry of Environment. 2008. Technology development for restoration natural ecosystem of urban artificial ground (Report No. 051-051-021). Sejong, Korea: Author.

Ministry of Environment. 2016. Development of urban artificial ground ecosystem adaptation and management technique (Report No. 416-111-016). Sejong, Korea: Author.

Nagase, A. and N. Dunnett. 2010. Drought tolerance in different vegetation types for extensive green roofs: Effects of 
watering and diversity. Landsc. Urban Plan. 97(4):318-327. https://doi.org/10.1016/j.landurbplan.2010.07.005

Park, J.S., J.H. Park, J.H. Ju, and Y.H. Yoon. 2010. Effects of planting soil on the soil moisture and the growth of Vitex rotundifolia for green roof. J. Korean Inst. Landsc. Archit. 38(3):98-106.

Schroll, E., J. Lambrinos, and D. Sandrock. 2009. Irrigation requirements and plant survival on northwest green roofs. Paper Presented at the Annual Greening rooftops for Sustainable Communities Conference. Atlanta, GA.

Sohn, K.H. 2012. Presentation of checklists for selection of herbaceous plants in garden design. J. Korean Soc. People Plants Environ. 15(1):47-60.

Sohn, K.H. 2013. Classification of Korean garden perennial plants according to growth habit, flower color, plant height, and flowering month. J. Korean Soc. People Plants Environ. 16(6):383-400. https://doi.org/10.11628/ ksppe.2013.16.6.383

Terri, J.A., M. Turner, and J. Gurevitch. 1986. The response of leaf water potential and Crassulacean acid metabolism to prolonged drought in Sedum rubrotinctum. Plant Physiol. 81(2):678-680. https://doi.org/10.1104/pp.81.2.678

Vahdati, N., A. Tehranifar, and F. Kazemi. 2017. Assessing chilling and drought tolerance of different plant genera on extensive green roofs in an arid climate region in Iran. J. Environ. Manag. 192:215-223. https://doi.org/10. 1016/j.jenvman.2017.01.027 